\title{
Rauhanvakaumus ja rauhankasvatus
}

\begin{abstract}
Arnkil, Erik. 1983. Rauhanvakaumus ja rauhankasvatus. Aikuiskasvatus 3, 2, 52-60. - Artikkelissa lähestytään rauhankasvatusta psykologisten ja pedagogisten käsitteiden avulla. Pyrkimyksenä on tarkastella rauhankasvatusta persoonallisuuden kehityksen yhteydessä ja erityisesti omakohtaisen vakaumuksen muodostumiseen vaikuttavia tekijöitä. Artikkelissa hahmotetaan myös rauhankasvatuksen tehtäviä eri ikäkausina.
\end{abstract}

\begin{abstract}
',Rauhankasvatus"' on nopeasti noussut puheenaiheeksi. Vielä muutama vuosi sitten vain muutama opettaja teki vakavaa työtä rauhankasvatuksen parissa. Nyt laajat opettajajoukot tuntevat tarvetta ja kiinnostusta asiaan. Viranomaiset ovat antaneet suosituksia ja kannanottoja. "'Rauhantahtoisuuteen kasvattaminen" kirjattiin tavoitteeksi uuteen koululakiin ja päivähoitolakiin.

Käsite "rauhankasvatus" ei kuitenkin ole yksiselitteinen ja sitä tulkitaan vaihtelevin, jopa keskenään ristiriitaisin tavoin. Epäselvyyttä on niin rauhankasvatuksen tavoitteiden, sisällön kuin menetelmienkin ymmärtämisessä.
\end{abstract}

\section{Heilahdukset rauhan- liikkeessä - ajateltavaa pedagogeille}

Rauhanliike on kasvanut valtavasti Suomessa ja muualla maailmassa. Se tempaisi 80luvun alussa mukaansa nuoria ja laajeni uusiin väestökerroksiin. Puhutaan "uudesta rauhanliikkeestä'. Mutta kuinka pysyvästä ilmiöstä on kysymys?

Myös 60-luvun lopulla tapahtui rauhanliikkeen nopea kasvu, joka kuitenkin kutistui 70luvun puolivälin tienoilla. Monet Vietnamin sodan vastustajat, solidaarisuustyön tekijät jne. passivoituivat. 70-luvun rauhanliikkeen taustalla oli suurvaltasuhteiden ja strategisen tasapainon vakiintuminen. 80-luvun liikehdinnän pohjana on voimatasapainon horjuminen ja sodanuhkan kasvu. Myös eri maiden sisäiset olot ovat muuttuneet. (Kansainvälis-poliittisista muutoksista ks. Väyrynen 1983).
Rauhanliikkeen kehitys riippuu tietysti ensisijaisesti kansainvälisestä ja kotimaisesta yhteiskunnallisesta kehityksestä eikä eri instituutioiden antamasta rauhankasvatuksesta. Rauhankasvatuksella voi kuitenkin olla merkitystä ihmisten orientoimiseksi toimimaan muuttuvissa oloissa.

Ilmeisesti 70-luvun puolivälin tienoilla rauhantyöstä vetäytyneiden ihmisten suuntautuneisuus ei kestänyt muutoksia kansainvälisessä ja kotimaisessa tilanteessa tai henkilökohtaisissa elämäntilanteissakaan (työelämään ja ammatteihin astumisen, perheiden muodostamisen, kulutuksen houkutusten jne. tuomat haasteet; puhutaan ',yksityistymisestä', '’keskiluokkaistumisesta" jne.). Niinpä on tärkeää miettiä voisiko rauhankasvatus antaa sellaisen orientaation, suuntautuneisuuden, joka kestää huomattaviakin muutoksia toiminnan kohteessa ja ehdoissa. Voisiko rauhankasvatus siis tuoda rauhantyön osaksi yksilön elämäntehtävän käsittämistä, vakaumukseksi?

\section{Persoonallisuuden suuntautuneisuus, vakaumukset}

Leontjevin mukaan persoonallisuuden rakenteen muodostaa tärkeiden, keskenään hierarkkisten motivaatiosuuntien suhteellisen pysyvä järjestys. Persoonallisuudella on tietty suuntautuneisuus, vaikka motivaatioalue onkin aina monihuippuinen. (Leontjev 1977, 181). Boshowitschin (1970) mukaan persoonallisuuden suuntautuneisuus on käyttäytymisen säätelyn ydin ja johtava elementti. (282-283).

Persoonallisuuden suuntautumisjärjestelmään kuuluvat eritasoiset motivationaaliset tekijät alkaen herätteistä, onnistumisiin ja epäonnistumisiin liittyvistä tunnelatauksista yms. päätyen konkreettisten tavoitteiden kautta henkilökohtaisiin motiiveihin, vakaumuksiin 
ja ihanteisiin. (Pehunen ja Lahtela 1982, 3536).

Vakaumukset kokoavat yhteen yksilön maailmankatsomuksen, tiedot, asenteet ja moraaliperiaatteet. Siksi niiden lähempi tarkastelu on erityisen hyödyllistä rauhankasvatuksen tavoitteen täsmentämiseksi: "Vakaumukset ovat persoonallisuuden tiedostettujen tarpeiden järjestelmä, joka ohjaa yksilöä käyttäytymään näkemyksiensä, periaatteidensa ja maailmankatsomuksensa mukaisesti. Vakaumusten muodossa esiintyvien tarpeiden sisällön muodostavat tiedot ihmistä ympäröivästä luonnosta ja yhteiskunnasta ja niiden ymmärtäminen"' (Petrovski, toim. 1974, 139).

Vakaumusten määrittelemiseksi on kuitenkin syytä ottaa huomioon N.S. Nasarowan huomautus tunteiden ja kokemusten osuudesta: 'Tietojen olemassaolo ja varmuus siitä, että ne ovat oikeita, muodostavat vakaumuksen olennaisen tunnusmerkin. Tămă tunnusmerkki ei kuitenkaan ole ratkaiseva. Vakaumuksen olemus on siinä, että tiedot, joiden oikeellisuudesta olemme vakuuttuneita, ankkuroituvat tunteisiin ja saavat vahvistuksensa henkilökohtaisissa kokemuksissa. Vasta silloin ne synnyttăvăt tarpeen moraaliseen käyttăytymiseen ja muodostuvat persoonallisuuden käyttäytymisen săăntelijöiksi”' (Nasarowa 1976, teoksessa Engeström 1979, 18-19). Toisin sanoen, vakaumusten sisältönă ja perustana ovat tiedot ja niiden ymmärtäminen. Jotta ne johtaisivat moraalista käyttäytymistä ohjaavien vakaumusten muodostumiseen, tietojen täytyy ankkuroitua tunteisiin ja saada vahvistuksensa kokemuksissa. 'Tiedot ja niiden ymmärtäminen' muodostavat yksilön "sisäisen mallin", jonka pohjalta hän toimii, ts. toiminnan orientaatioperustan. Toimiessaan orientaationsa pohjalta yksilö koettelee, täydentää ja korjaa orientaatioperustaansa (tai kuten Nasarowa sanoo, tiedot saavat vahvistuksensa henkilökohtaisissa kokemuksissa). Orientaatioperusta lähemmin tuonnempana.

Edellä todetun pohjalta voidaan hahmotella rauhanvakaumusta ja nähdä siinä kolme "perusosaa":

Kuvio 1. Rauhanvakaumus

\begin{tabular}{|l|}
\hline \multicolumn{1}{|c|}{ RAUHANVAKAUMUS } \\
\hline \multicolumn{1}{|c|}{$\begin{array}{l}\text { Tiedot ja } \\
\text { niiden ymmärtäminen }\end{array}$} \\
$\begin{array}{l}\text { Tunteet, } \\
\text { joihin tiedot } \\
\text { ankkuroituvat }\end{array}$ \\
\hline
\end{tabular}

Jos tarkastellaan rauhankasvatusta, joka vaiheittain voisi muodostaa rauhanvakaumusta, ts. kestävää suuntautuneisuutta rauhantyöhön, on vastattava kolmeen periaatteelliseen kysymykseen ja jatkokysymykseen:

1) Mitkä tiedot - ja miten ne opetetaan?

2) Mitkä tunteet - ja miten tiedot "'ankkuroituvat" tunteisiin?

3) Mitkä kokemukset - ja miten ne vahvistavat tiedot?

\subsection{Mitkä tiedot?}

Tässä käsitellään vain rauhankasvatuksen sisällön muodostamisen periaatteita, opetettavalle orientaatioperustalle asetettavia ehtoja. Metodeja ei sen sijaan käsitellä. Olen käsitellyt niitä konkreettisten esimerkkien valossa Koulutyöntekijälehden numeroissa 3/82 ja 4/82.

Rauhantutkimuksessa "'rauhaa"' koskevat käsitykset on usein jaoteltu kahteen eritasoiseen käsitteeseen "negatiivinen rauha"' ja "positiivinen rauha"'. Negatiivisella rauhalla tarkoitetaan sellaista tilannetta valtioiden välillä, jossa väkivaltaa aiheuttavat rakenteet ja ristiriidat ovat olemassa, mutta konflikti ei ole avoimen väkivallan tasolla. Positiivinen rauha kattaa sekä valtioiden välisen että niiden sisäisen tilanteen. Sillä tarkoitetaan monipuolista, kaikkia osapuolia hyödyttävää ja tasavertaista vuorovaikutusta; rauha on seurausta väkivallan syiden syrjäytymisestä. (Ks. esim. Young 1981, 123-134). Erottelu voidaan tehdä myös käsitteillä "yhteiskunnallinen epäoikeudenmukaisuus" ja "yhteiskunnallinen oikeudenmukaisuus".

Tämä jaottelu "rauhan" käsittämiseen eri tasoilla näkyy myös rauhankasvatuskokeiluissa ja -kaavailuissa. "'Ruohonjuuritasolla" on meillä ja muualla Länsi-Euroopassa yritetty löytää keinoja nuorten aktivoimiseksi toimintaan euro-aseita, neutronipommia, asebudjettien paisuttamista jne. vastaan, ydinasejäädytyksen, ydinaseettomien vyöhykkeiden jne. puolesta. "Asiantuntijatasolla", rauhantutkimuksen ja Unescon piirissä on taas painotettu enemmän sotien ja varustelun yhteiskunnallisten taustatekijöiden paljastamista ja muuttamista. (Ks. esim. Haavelsrund, ed. 1981 ja Seppä \& Vesa, toim. 1982).

Ruohonjuuritason liikkeen voima on ollut sen "tämänpäiväisyydessä" ja yksilöiden (ja ryhmien) toiminnallisten tehtävien osoittamisessa. Sen heikkous on kuitenkin ollut näköalojen ja toiminnallisten mahdollisuuksien suppeudessa. On ikäänkuin tarjottu valmiita malleja toiminnasta (euroaseet - - marssit) ja rauhantoiminta ikäänkuin koostuu erilais- 
ten "negatiivisen rauhan" etappien ketjusta (ydinaseeton Pohjola - - ydinaseeton Eurooppa - - ydinaseeton...). Koska varustelun ja sotien yhteiskunnalliset taustatekijät ovat jääneet vähälle huomiolle, välillisesti varusteluun liittyvät asiat ovat peittyneet näkyvistä. Näin on myös menetetty mahdollisuuksia nähdä välillisiä, rakenteita vähitellen murtavia, vaikutusmahdollisuuksia.

\subsubsection{Mitä ovat välilliset tekijät?}

Tätä kysymystä voidaan lähestyä esimerkiksi tarkastelemalla asevarustelun ja maailmanmarkkinarakenteen yhteyksiä. Tämä on tietysti vain yksi esimerkki. Kolmas maailma on maailmanmarkkinoilla halpojen raaka-aineiden ja energiavarojen sekä työvoiman alipalkattujen palvelujen tuottaja. Kehitysmaiden osuus kehittyneiden maiden raaka-aine- ja energiatuotannossa on niin keskeinen, että esim. Yhdysvaltojen talouskasvu ei voisi toteutua ilman kehitysmaiden hyväksikäyttöä. Länsi-Eurooppa on vielä riippuvaisempi tuontiresursseista ja Japani on niistä täysin riippuvainen (ks. esim. Hveem 1979, Käkönen 1980, Väyrynen 1980). Sosialististen maiden suhteet kehitysmaihin ovat toisenlaiset, johtuen ennen muuta Neuvostoliiton raaka-aineomavaraisuudesta. (Ks. Hveem mt.). Kehitysmaiden hyväksikäyttö tapahtuu markkinarakenteen avulla: raaka-aineet ovat halpoja ja teollisuustavarat kalliita. Kehitysmaissa tapahtuva tuotanto, tuotteiden kuljetus sekä markkinointi ovat monikansallisten, läntisten yritysjättien otteessa. Se taloudellinen vauraus, joka on lännen varustelun taustalla, pohjautuu pitkälti kehitysmaiden hyväksikäyttöön. Jos kehitysmaat onnistuisivat rakentamaan ns. omaehtoista kehitystä ja vähentämään riippuvuuttaan monikansallisista yhtiöistä, ei lännen talous voisi jatkaa entiseen tapaan ja asevarusteluakin olisi pakko sopeuttaa kaventuneisiin resursseihin. Niinpä mieluummin säilytetään muuttumaton tilanne, "status quo". Kehitysmaat ovat joutuneet lännen talouskasvun ja asevarustelun "maksumiehiksi" - ja asevarustelua "tarvitaan' osaltaan juuri tämän suhteen ylläpitämiseen. (Ks. Antola 1977 ja 1978, Käkönen mt.).

Kehitysmaat ovat joutuneet myös suoremmin "takaajiksi" asevarustelussa. Ne tuottavat huomattavan osan ns. strategisista raakaaineista, joita ilman nykyaikaisia aseita ei voi valmistaa, tai pitää toiminnassa (mm. öljy, kromi, kupari, titaani, platina, koboltti). (Neuvostoliitto on năidenkin suhteen käytănnöllisesti katsoen omavarainen). Niinpă asevarustelun ylläpitäminen "vaatii" status quon säilyttämistä erityisesti strategisten raakaaineiden tuottajamaissa, mm. Etelä-Afrikan tasavallassa, Namibiassa ja Zairessa. (Ks. Hveen 1979). Status quon ylläpitäminen merkitsee näiden kohdalla rotusorron, laittoman miehityksen ja diktatuurihallinnon suojelua, mm. YK:n toimenpiteitä jarruttamalla.

Johtopäätös: kehitysmaiden omaehtoisen kehityksen tukeminen on epäsuoraa mutta tehokasta työtä rauhan puolesta, se on "positiivisen rauhan" rakenteiden muodostamista. Rotusorron ja ns. uuskolonialististen markkinarakenteiden vastustaminen ei ainoastaan liity rauhantyöhön. Se on rauhantyötä. (Omaehtoisen kehityksen tukeminen ei ole ilman muuta yhtä kuin kehitysavun lisääminen. Suurin osa nykyisestä kehitysavusta tukee olemassaolevaa markkinarakennetta ja hyödyttää enemmän monikansallisia yhtiöitä kuin kehitysmaiden asukkaita. Ks. mm. Wihtol 1978). Mikäli nuorille ja aikuisille avataan ylläkuvatun kaltaisia toiminnallisia yhteyksiä, heille avautuu "valmiita malleja" laajempi näköala rauhantyöhön. Rauhankasvatuksen tehtävänä olisikin avata oppilaille yksilö - - maailma -suhde mahdollisimman laajasti. Mikäli yksilö näkee varustelevan maailman systemaattisena ja historiallisesti kehittyvänä kokonaisuutena, hänen on mahdollista itsenäisesti johtaa toimintatehtäviä ihanteidensa toteuttamiseksi (vähitellen, kärsivällisesti) sellaisissakin oloissa, joissa suppeamman orientaation omaava henkilö ei mahdollisesti näe lainkaan vaikutusmahdollisuuksia. Vakaumus tarvitsee "ruokaa". Yksilön tulee sekä voida nähdä keinoja toimia vakaumuksensa mukaisesti että saada jatkuvasti vahvistusta vakaumukselleen, ts. kokemuksia, jotka vahvistavat vakaumuksen perustana olevat tiedot (niiden muodostaman kokonaisnäkemyksen, orientaatioperustan) ja täydentävät niitä. Mikäli minulla on vain kapea-alainen "negatiivisen rauhan" käsitteen mukainen orientaatio maailmaan, tulee ratkaistavakseni tilanteita, joita "mallini" ei ehkä kata. En näe toiminnallisia mahdollisuuksia. (Kansainvälispoliittinen tilanne muuttuu minulle käsittämättömällä tavalla, joudun erilleen turvallisèsta ja toimintamallin antaneesta ryhmästä jne.). Vaikka tiedotusvälineet olisivat tulvillaan aineistoa, joka kertoo väkivallan ja varustelun rakenteiden văhittăisestä murtumisesta ja siis "ruokkii" vakaumustani, en osaa tulkita sitä, en ymmärrä tietojen yhteyttă "malliini".

Edellä on arvosteltu ruohonjuuritason rauhankasvatustradition heikkouksia. Myös "asiantuntijatason" traditiolla on voimansa ja heik- 
koutensa. Voimana on rauhan ymmärtäminen syvällisemmin ja dynaamisemmin - taustalla olevista rakenteista käsin. Heikkoutena taas on ollut yksiloiden ja ryhmien toimintamahdollisuuksien vähäinen tarkastelu (juuri se, mitä "ruohonjuuritaso" on korostanut). Rauhantutkijoiden kirjoituksissa rakenteet ikäänkuin muuttavat itseään tai sitten muuttuvat "yhteiskuntien" tai "valtioiden" tai "kansainvälisen yhteisön" toimesta. Toimivia ihmisiä ei näy missään. Rauhankasvatus on tavallaan valistuneiden kuluttajien kasvattamista: kasvatetaan ihmisiä, jotka ymmärtävät uutisten taustoja jne, mutta eivät tee toiminnallisia johtopäätöksiä. Toiminta jätetään "päättäjien" huoleksi. (Esimerkki tăllaisesta otteesta on mm. kouluhallituksen Aseidenriisuntakasvatuksen työryhmän raportti vuodelta 1981).

Selvästikin tehtävänä on yhdistää edellä mainittujen "traditioiden" parhaat puolet ja voittaa niiden heikkoudet. Pitäisi siis päästä sellaiseen rauhankasvatuksen sisältőon, jossa "näkyy" yksilöiden ja ryhmien toiminta sekä välittơmien että pitkän tähtäimen tehtävien hyväksi. (Tässä yhteydessä haluan huomauttaa, että vaikka olen arvostellut "suppeita toimintamalleja", en missään nimessä tarkoita, etteikő toiminta asevarustelun pysäyttämiseksi, euroaseiden torjumiseksi ja ydinaseettoman Pohjolan aikaansaamiseksi olisi mitä tärkeintä. Rauhantyöllä on toki kiireellisyysjärjestys. Mutta emme saisi täysin samastaa rauhankasvatusta ja rauhanaktioita. Muutoin joudumme jälleen vaikeuksiin, kun olosuhteet muuttuvat).

\subsubsection{Rauhantoiminan orientaatioperusta}

Edellă on viitattu useaan otteeseen orientaatioperustan käsitteeseen. Monet lukijat tuntevat neuvostoliittolaisen psykologin P.J. Galperinin teoriaa orientaatiosta ja orientaatioperustoista (ks. mm. Galperin 1979). Galperinin mukaan ihminen suorittaa tekonsa tietyn subjektiivisen kuvan varassa. Tämä kuva sisältää käsityksen edessä olevasta teosta ja sen ympäristơstä tai ehdoista. Tăllaista kuvaa nimitetään orientaatioperustaksi. Se voi olla tietyn teon suorittamista varten täydellinen tai epätäydellinen, tarkoituksenmukainen tai epätarkoituksenmukainen, oleellista tai epäoleellista informaatiota sisältävä (ks. myős Talyzina 1981, 88-100 ja Engeström 1982a ja 1982b).

Galperin on kehitellyt erityisesti yksittäisen teon orientaatioperustaa. Teot ovat kuitenkin toiminnan "osia". Toiminta muodostuu teko- jen ketjuista. Teot ovat aina osa toimintaa (Leontjev 1977, 93).

Rauhankasvatuksessa tarkastelun kohteena on rauhantoiminta. Tekoja tarkastellaan yhteydessä kokonaisuuteen.

Toiminta rauhan puolesta koostuu useista "'lohkoista" ja vălitavoitteista. Yksilőn käsitys siitä, miten nămä lohkot ja vălitavoitteet liittyvăt toisiinsa ja kokoavaan tavoitteeseen, motiivitavoitteeseen (väkivallan rakenteiden purkaminen), ja kuinka hänen tekonsa muodostavat ketjuja, muodostaa hänen toiminnan orientaatioperustansa. Tässä ovat "'edustettuina" (tiivistettynä sisäisenä "mallina') toiminta"' (tiivistettynä sisäisenä mallina) toiminnan kohde ("maailma", "väkivallan rakenteet"), muutoksen voimat ("rauhanvoimat", joista yksilo itse on yksi) ja muutoksen keinot.

Vaikka orientaatioperusta ilmenee yksilöllisesti - yksiloiden tajunnassa - se on $y \boldsymbol{h}$ teiskunnallisen toiminnan orientaatioperusta. Rauhantyơtä ei toteuta joukko eristettyjä yksilöitä, vaan kollektiivinen subjekti, rauhanliike (tai "rauhanvoimat"). Yksilö - maailma -suhde, jota edellä tarkasteltiin, kuuluisi siis kirjoittaa yksilo - ja muut rauhanvoimat _- maailma!

Mistä aineksista sitten voisi muodostaa toiminnan orientaatioperustan, useat osatavoitteet yhteen kokoavan kokonaisnäkemyksen ts. millä periaatteella valitaan, kootaan ja järjestetään rauhankasvatuksen sisältő?

Vaikka "rauhankasvatuksen"' määrittely on Unescossa saanut vaihtelevia otsikoita (vuonna 1974 puhuttiin kasvatuksesta kansainväliseen ymmärtämykseen, yhteistyöhön ja rauhaan, 80-luvulla tuli esiin käsite aseidenriisunta- ja rauhankasvatus, vuonna 1980 kesällä järjestettiin "Aseidenriisuntakasvatuksen "'konferenssi. Ks. lähemmin Unesco 1974 ja Seppä \& Vesa 1982), sen koostumus on nähty johdonmukaisesti samana. Rauhankasvatus koostuu Unescon mukaan ihmisoikeuskasvatuksesta, kehityskasvatuksesta ja aseidenriistuntakasvatuksesta. Kukin näistä kolmesta käsitteestä on määriteltävä suhteessa kahteen muuhun. (Unesco 1980 § 7 teoksessa Seppä \& Vesa 1982, 17). Ei siis voida ymmärtää ihmisoikeuksien toteutumista riippumatta kehityksestä ja aseriisunnasta, kehitystä irrallaan ihmisoikeuksista ja aseriisunnasta ja aseriisuntaa irrallaan yhteiskunnallisista taustatekijoistään. Unescon suoritusten mukainen rauhankasvatus voitaisiin kaaviona kuvata seuraavasti: 


\begin{tabular}{|l|l|l|}
\hline \multicolumn{3}{|c|}{ RAUHANKASVATUS } \\
\hline $\begin{array}{l}\text { IHMIS- } \\
\text { OIKEUS- }\end{array}$ & KEHITYS- & ASEIDEN- \\
KASVATUS & & RIISUNTA- \\
KASVATUS \\
\hline
\end{tabular}

(Nykyisin korostetaan myös tasa-arvokasvatusta. Se voidaan mielestäni ymmärtää osaksi ihmisoikeuskasvatusta).

Mikäli tavoitteena on kokonaisuuden muodostaminen, jossa ihmisoikeudet, kehitys ja aseriisunta (ja kääntäen ihmisoikeusloukkaukset, alikehitys ja asevarustelu) muodostavat yhtenäisen dynaamisen kokonaisuuden, tulee pyrkiä rakentamaan teoreettinen malli. Opetus ei voi olla irrallisten faktojen välittämistä. Kokonaisnäkemys ei myöskään voi olla pysähtynyt, jähmeä, valokuvamainen, vaan varustelevan maailman kehitystä selvittävä. Ei myöskään riitä varusteluun liittyvän tietoaineiston luokittelu ulkoisten yhtäläisyyksien pohjalta, varustelevien maiden asejärjestelmien tms. vertailu ulkoisten tunnusmerkkien perusteella jne. Tarvitaan käsitteitä, jotka selittävät vuorovaikutussuhteita ja historiallisen kehityksen syita.

Tällaisen "mallin" muodostaminen olisi rauhantutkimuksen tehtävä. Pedagogien taholla on tehty työtä kokonaisnäkemyksen muodostamiseksi rauhantutkimuksen usein sangen kapea-alaisten tarkasteluotteiden ja tulosten yhdistämiseksi (ks. Koulutyöntekijä $3 / 82$ ja $4 / 82$ ).

Tehtävänä on siis teoreettisten käsitteiden opettaminen siten, että oppilaalle/opiskelijalle muodostuu kokonaisnäkemys, orientaatioperusta, jossa yhdistyvät niin "negatiivisen" kuin "positiivisenkin rauhan" tehtävät. Tällaisen orientaatioperustan opettaminen tapahtuu vaiheittain. Palaan tähän tuonnempana, ikäkausitehtävien yhteydessä.

\subsection{Mitkä tunteet - ja miten tie- dot ankkuroituvat tunteisiin?}

Rauhanvakaumuksen taustalla on käsittäakseni rakkaus elämään - ihmisiin, luontoon, kulttuuriin. Tämän rakkauden herättäminen (tai pikemminkin ruokkiminen) on perustehtävä.

Rakkaus elämään synnyttää myös kielteisiä tunteita: Tuskaa elämän tuhoamisesta, sorrosta, vääryydestä, vihaa sodanlietsonnasta.

Rauhankasvattajan tulisi erityisesti harkita miten tiedot ja tunteet ankkuroituvat toisiinsa.
Sangen usein näkee rauhankasvatukseen tarkoitettuja materiaaleja, joissa on "tunteisiin vetoavaa" aineistoa, joka kuitenkin on sijoitettu opetukseen pohtimatta millaiseen tietoperustaan tunne-elämykset kytkeytyvät. Äärimmäisyyden muodostavat aineistot, joissa on shokeeraavaa kuva- ym. materiaalia "'herättämässä" kasvatettavia toimintaan.

Usein viitataan taiteen mahdollisuuksiin tehdä käsitellyt ongelmat omakohtaisiksi oppilaille (ks. mm. Kekkonen 1982a ja 1982b). Taiteella ilmeisesti onkin oma voimansa: "Ilman emotionaalista suhdetta todellisuuteen ei voi olla siihen kohdistuvaa toimintaa. Toisaalta, jos esteettiset kohteet olisivat vain tunteeseen vetoavia, olisi niiden vaikutus vain hetkellinen"' (Viljo 1976 artikkelissa Onnismaa 1982, 7). Teplovin mukaan taiteen havaitsemisen tulisi alkaa välittömillä tunteilla, minkä jälkeen havainto voi johtaa perinpohjaiseen ajatteluun (Teplov 1963 artikkelissa Onnismaa 1982). Taide voi olla perinpohjaisen ajattelun herättajä, mutta ilman teoreettisia käsitteitä yksilö ei kykene "perinpohjaiseen ajatteluun". Ilman selittäviä käsitteitä voimme. joutua ymmälle tai täysin harhaankin "tunteisiin vetoavan" rauhankasvatuksen pohjalta.

Tiedot ja tunne-elämykset olisikin vietävä rinnan ja kytkettävä toisiinsa kaikessa opetuksessa. Ei siis niin, et tä historian opinnoissa annetaan kantaaottamattomia (ja siis pinnallisesti selittäviä) tietoja ja vaikkapa taideopinnoissa järisytetään tunteita. Pikemminkin pitäisi etsiä tietojen ja tunteiden "ankkuroimispisteitä’' opiskeltavan kohteen avainkäsitteitä.

\subsection{Mitkä kokemukset - ja miten ne vahvistavat tiedot?}

Neljä lyhyttä teesiä kokemuksista:

Ensiksi. Kasvatusinstituutioiden ovet on avattava rauhanliikkeelle. Olisi löydettävä keinoja sekä oppilaiden ja opiskelijoiden "erityisen" rauhantoiminnan lisäämiseksi että ''kasvatuksen ulkopuolelta" tulevan rauhanliikkeen tien avaamiseksi kasvatusinstituutioihin. Mielestăni on tärkeätä, että rauhankasvatukseen liittyväă rauhantoimintaa ei mielletä "'tavallisesta rauhantoiminnasta" irralliseksi pedagogiseksi puuhailuksi. Sen tulisi olla muoto, jossa opiskelijat osallistuvat yhteiskunnalliseen toimintaan ja jossa he "testaavat", koettelevat, täydentävät ja korjaavat näkemyksiään ja tietojensa kokonaisuutta, orientaatioperustaansa.

Toiseksi. Opettajat ja muut kasvattajat ovat erittäin keskeisessä asemassa "sanojen ja teko- 
jen ykseyden" kannalta. Kasvattaja, joka ei itse luota rauhantyöhön eikä siihen osallistu, saa tuskin kovin syviä muutoksia aikaan kasvatettaviensa tajunnassa, vaikka puhuisikin rauhantyön tarpeellisuudesta.

Kolmanneksi. Olisi osattava tarttua oppilaiden oman toiminnan nostamiin periaatteellisiin ongelmiin ja auttaa heitä syventämään niiden tarkastelua. Oppilaiden päivittäinen toiminta ja keskinäiset suhteet tuovat esiin ongelmia ja ristiriitoja sekä myönteisiä kokemuksia, joissa esiintyy itumuodossaan periaatteellisiakin kysymyksiä. Näihin olisi osattava tarttua ja "ruokkia" pohdintoja.

Neljänneksi. Rauhankasvatusta pohdittaessa on syytä miettiä myös mitä oppimistoiminnan järjestämiselle on tehtävä. Mikäli on tarkoitus kasvattaa tavoitteellisesti toimivia ihmisiä, on päästävä eroon käytännöstä, jossa oppilaat ovat tahdottomia objekteja. Mikäli opiskelijoiden on tarkoitus oppia, että tieto on tärkeätä todellisuuden ymmärtämiseksi ja muuttamiseksi, on päästävä käytännőstä, jonka mukaan on samantekevää mitä luetaan kunhan saadaan hyviä arvosanoja. Mikäli on tarkoitus kasvattaa kriittisyyteen, pitää selittävien periaatteiden, käsitteiden ja "mallien" opiskelu järjestää niin, että opiskeltavia orientaatioperustoja koetellaan ja "testataan" jatkuvasti. Jos tarkoituksena on kasvattaa kollektiivisesti toimivia rauhan puolustajia, on opiskelun pohjauduttava keskinäiseen yhteistyőhön. (Oppimistoiminnan järjestämisestä näiden periaatteiden mukaan ks. Dawydow, Lompscher, Markowa 1982).

\section{Ikäkausitehtävistä}

On selvää, että ''ihmisoikeuksien, kehityksen ja aseriisunnan" muodostaman kokonaisuuden teoreettinen omaksuminen voi varsinaisesti tapahtua vasta varsin varttuneiden nuorten sekä aikuisten opiskelussa. On kuitenkin huomattava, että tälle ' 'kehittyneelle tasolle" ei päästä suoraa tietä, ilman tiettyjen ehtojen täyttämistä. Näen mielessäni kaksi perusehtoa: kokonaisuuden, varusteludynamiikan "'mallin"', haltuunotto vaiheittain käsitejärjestelmän avulla ja humaanin arvoperustan muodostaminen. Nämä kaksi liittyvät yhteen.

Miten rauhankasvatuksen ikäkausitehtäviä voisi hahmottaa? Mielestäni ne löytyvät yhdistämällä seuraavat neljä "'lähestymistietä':

1) nuorten ja aikuisten olojen ja arkiajattelun tutkiminen

2) sisällön, käsitejärjestelmien, määräämä vaiheittainen etenemisjärjestys,
3) oppimisen määrittämät ehdot (oppimispsykologian ja kasvatustieteen perustalta nähdyt reaaliset mahdollisuudet) ja

4) kehityspsykologiset ehdot (ikäkausien kehitystehtävien huomioiminen).

\subsection{Nuorten ja aikuisten olot ja arkiajattelu}

Jotta rauhankasvatus voi viedä kasvatettavien tietoisuutta eteenpäin, on tunnettava tuo tietoisuus. Nuorten ja aikuisten arkiajattelu sisältää kysymyksiä ja ristiriitoja, joihin tarttumalla voidaan synnyttää ja edistää heidän omaa tiedontarvettaan. Jotta kasvattajan "tarjoamat"' kysymyksenasettelut eivät olisi motivoivia ainoastaan kasvattajalle, ongelmat ja tehtävät on pohjattava kasvatettavien tietoisuudessa itumuodossaan oleviin kysymyksiin ja ristiriitoihin arkiajattelussa. Nämä on siis tunnettava. Se on vakavan tutkimuksen tehtävä, ja tällaista tutkimusta meillä on vähän. "Tiedämme", että lapsilla, nuorilla ja aikuisilla on sodanpelkoja ja käsityksiä "tavallisten ihmisten" vaikutusmahdollisuuksista. Mutta tietomme ovat määrällisiä gallup-tilastoja. Tiedämme hyvin vähän arkiajattelun laadusta.

\subsection{Sisällön määräämä etenemisjärjestys}

"Kehittyneeseen analyysiin" ei voi hypätä tyhjästä. Tarvitaan käsitteitä, joiden opetminen on pitkällinen tehtävä. Se, mitä käsitteitä tarvitaan ja missä suhteessa käsitteet ovat toisiinsa, riippuu varustelua ja sen poistamista koskevan teoreettisen selitys"mallin" rakenteesta ja sisällöstä. Kun kokonaisuus on muodostettu, sitä voidaan "purkaa osiin": nähdään mitkä käsitteet ovat edellytyksenä seuraavalla abstraktiotasolla olevien käsitteiden haltuunotolle jne. (Jos esim. on tarkoitus analysoida vaikkapa kehittyneiden kapitalististen maiden ja kehittyneiden sosialististen maiden keskinäissuhteita, käsitteet '"kapitalismi"' ja "sosialismi" ovat aivan perustavia käsitteitä. Olemme (työryhmä Erik Arnkil, Arvi Kylliäinen ja Antti Penttilä) yrittäneet toteuttaa aseriisuntakasvatuksen opetuskokeiluja lukiossa ja havainneet, että tietyt peruskäsitteet on niin hatarasti opittu aikaisempina kouluvuosina, ettei niiden varaan voi rakentaa. Tehtävänä on näiden käsitteidenkin, eikä vain niillä operoinnin, opettaminen).

Yrityksemme luonnostella opetuskokonaisuuksia peruskoulun ala-asteelle, yläasteelle ja lukioon ovat vahvistaneet käsitystämme että Unescon esittämä jaottelu "ihmisoikeudet kehitys - aseriisunta" toimii tietyllä tavalla myős ikäkausitehtävien pohjana. Kysymys ih- 
misoikeuksista, ihmisten perustarpeiden yhtäläisyydestä ja yhtäläisistä perusoikeuksista, on pohjaa-antava koko rauhankasvatukselle. Rauhankasvatuksen ensimmäisiä tehtäviä on kasvattaa humaani suhtautuminen kaikkiin ihmisiin: lähimpiin, etäisempiin, muihin rotuihin ja vieraisiin kansoihin. Kysymys kehityksestä ja kehitysongelmista tuo tarkasteluun ihmisoikeuksien tilan ja niiden toteutumisen esteet suurimmassa osassa maapalloa. Tarkasteluun tulevat kehitysongelmien syyt ja keinot poistaa niitä, ts. solidaarisen kansainvälisen ajattelun peruselementit. Tarkasteluun tulevat jo yhteiskuntajärjestelmät ja niiden suhde ns. omaehtoiseen kehitykseen alikehittyneissä maissa. Tällaiseen tarkasteluun tarvitaan koko joukko teoreettisia käsitteitä. Olen tehnyt luonnoksia niiden opettamisesta peruskoulun 5. ja 6. luokkien maantiedonopetuksen yhteydessä (mainitut artikkelit Koulutyöntekijä-lehdessä).

Kysymys asevarustelun merkityksestä paljastaa vihdoin ihmiskunnan ongelmat koko laajuudessaan. Asevarustelu on se tiivistymäpiste, jossa keskeisimmät kansainväliset ongelmat ovat yhtä aikaa tarkastelun kohteena, kokonaisuuden selittäviä tekijoitä. Tarkasteluun kuuluvat jo maailmanjärjestelmien vastakkaisuuden ja kilpailun rauhanomaiset ja sotilaalliset muodot sekä järjestelmien sisäiset ristiriidat. Tällơin voidaan nähdä myös positiivisen rauhan puolesta tehtävän työn reaaliset tehtävät ja esteet. Yksilö - maailma -suhteet avautuvat yhtä aikaa moneen suuntaan.

Tässä yhteydessä hahmottuu selvästi myős rauhankasvatuksen tarjoama "viholliskuva": "vihollinen" on ne rakenteet, jotka tuottavat väkivaltaa ja varustelua; ihmiskunnan etu on poistaa ne.

Vaikka aseidenriisuntakasvatus vasta paljastaa koko laajuudessaan ihmisoikeudet-kehitysaseriisunta -yhteydet, näitä yhteyksiä voidaan ja pitäisi avata jo "ihmisoikeuskasvatuksen" ja "kehityskasvatuksen" puitteissa.

\subsection{Oppimisen teoria ja ikäkausitehtävät}

Rauhankasvatuksen tehtävänä on kasvattaa oppilaita pysyvään toimintaan rauhan puolesta. Toiminnan laatu perustuu ajattelun laatuun ja sen pysyvyys, kestävyys on riippuvainen orientaation laadusta. Tehtävänä on kehittää oppilaiden teoreettista suhdetta todellisuuteen, teoreettista ajattelua. Teoreettisen suhteen avulla yksilo hallitsee todellisuutta laajemmin ja syvällisemmin kuin kokemusperäisen tiedon perusteella.

On monia, jotka väittävät, että teoreettisten käsitteiden ja teoreettisen ajattelun oppiminen on ylivoimaista peruskoululaisille - etenkin nuorimmille. Tällaisten epäilijoiden soisi tutustuvan V.V. Dawydowin työryhmän kokeiluihin ja teoreettiseen tyőhön. (Ks. Dawydow 1977, Dawydow, Lompscher, Markowa 1982, Hakkarainen 1979). Voi olla, että aikuiskasvatuksenkin piirissä on henkilöitä, jotka epäilevät mahdollisuuksia opettaa teoreettisia käsitteitä esim. henkiloille, joilla ei ole "teoreettista" koulutusta.

Kysymys ei kuitenkaan ole oppimismahdollisuuksien muodostamista esteistä, vaan kehit-

Kuvio 2. Persoonallisuuden yksilökehityksen vaiheistus (Vygotskya, Elkoninia ja Bosovitsia mukaillen)
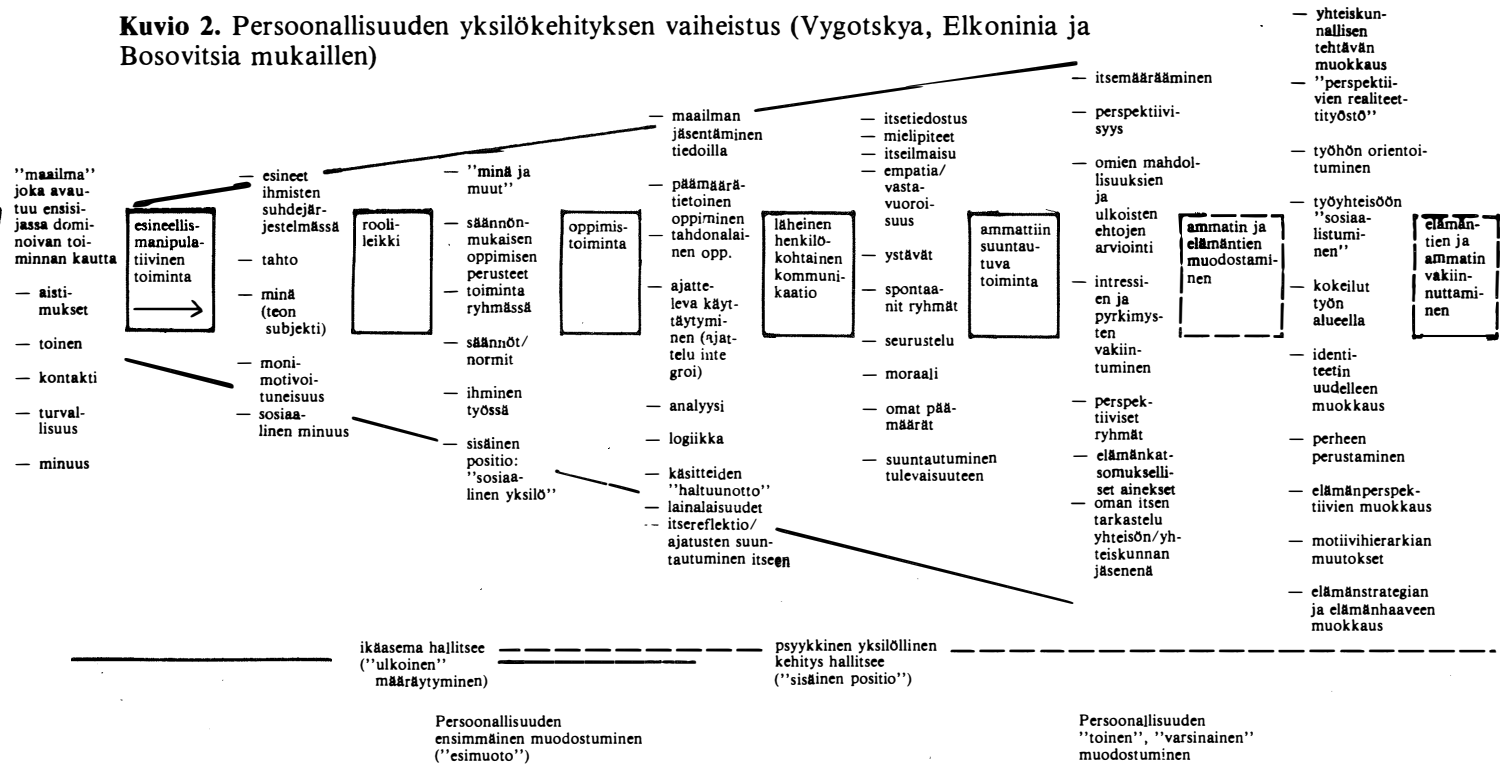
tymättömien opetusmenetelmien muodostamista esteistä. Rauhankasvatuksen kehittäminen edellyttää lujaa otetta oppimisen teoriasta ja tieteelliselle pohjalle rakennettua metodiikkaa.

\subsection{Kehityspsykologiset ehdot}

Ihmisen kehitys etenee vaiheittain. Hän ei pysty kehittymään "samanaikaisesti"' kaikessa, vaan uuden elämänalueen hallinnan omaksuminen välittyy tietyn tuolle ajankohdalle leimallisen hallitsevan toiminnan kautta. Erityisesti D.B. Elkonin on kehitellyt teoriaa ikäkausien hallitsevasta toiminnasta. (Ks. esim. Elkonin 1972). Rauhankasvatuksen tulisi ottaa huomioon ikäkausien kehitystehtävät ja auttaa kehittymässä olevan suhteen muodostumista tarkoitusperiensä mukaisesti. Robert Arnkil $(1981,19)$ on edellä olleen kaavion muodossa kuvannut hallitsevan toiminnan käsitteelle perustuvaa yksilönkehityksen vaiheittaisuutta. Yksilö elää ikään kuin laajenevassa maailmassa, jossa kussakin kehitysvaiheessa hallitseva toiminta avaa uusia puolia.

Aikuiskasvatus "koskettelee" ikäkausia, jolloin yksilölle hahmottuvat ja vakiintuvat ammatti ja elämäntiet. Usein kehityspsykologiset tarkastelut "loppuvat" ennen näitä vaiheita. Persoonallisuus ikään kuin "tulee valmiiksi" ennen aikuisikää. Kuitenkin sekä Leontjev että monet ns. Life-Span psykologit (Baltes \& Schaie (1973) etc) ja elämänrakennetta kokonaisuudessaan kuvaava Levinson (1978) korostavat, että n. $25-30$ vuoden iässä ihminen varsinaisesti muodostaa elämäntehtävänsä kooten ja käsitellen sitä kokemusta, joka hänellä on - aikaisemmin hänellä on ollut vähän mistä koota.

Persoonallisuuden kehitys ei toki lopu tähänkään. Vanhustutkimuksesta käsityksensä muodostaen ovat Pehunen ja Lahtela (1982) käsitelleet yksilöiden elämänstrategioiden muotoutumista ja vakiintumista laajan elämänkaaren aikana.

Aikuisiän rauhankasvatuksen olisi - kouluopetustakin selvemmin - kyettävä osoittamaan rauhantoiminnan kytkentöjä yksilöiden elämäntoiminnan kokonaisuuteen. Tärkeä osa tätä on ammatillinen toiminta, työn sisällöt. Harva ammatti tai toimi tarjoaa mahdollisuuksia kytkeä työn sisältö "'negatiivisen rauhan'" etappitehtäviin. Moni työ sen sijaan kytkeytyy positiivisen rauhan rakenteiden muodostamiseen. Jotta tällaisia kytkentöjä nähdään, tarvitaan laajaa orientaatioperustaa, välillistenkin yhteyksien ymmärtämistä.

Me suomalaiset voisimme esimerkiksi pohtia Suomen ja Neuvostoliiton suhteiden 'labora- toriotehtävää"'. Yhteistyömme muodot ovat rauhanomaisen rinnakkainolon rakenteita, uuden maailman suhteita. Moni työ kytkeytyy näihin. Tai voisimme pohtia Suomen asemaa maailmanmarkkinarakenteessa ja havaita, että meidän on toteutettava suuria muutoksia Suomen tuotantorakenteessa, mikäli emme aio jatkaa elämistä toisten kustannuksella. Yhä useampi työ nähdään yhteydessä "positiivisen rauhan" rakentamiseen.

Mikäli työn sisällöt kytkeytyvät rauhantoimintaan "rauha elämäntapana" ei supistu vain vapaa-ajan toiminnaksi ja käyttäytymistyyleiksi.

Aikuiskasvatus toimii vaiheessa, jossa vaarat persoonallisuuden psykologisen rakenteen "'litistymisestä"' ovat suurimmillaan. Rauhankasvatus voi olla keino muodostaa yksilöllisesti ja yhteiskunnallisesti tärkeitä motiiveja.

Rauhankasvatus on myös aikuiskasvatuksessa persoonallisuuden kasvatusta. Se yrittää saada aikaan aikuisopiskelijoiden motivaatiosuuntien järjestäytymistä rauhantoiminnan mukaisesti. Aikuiselämän rauhankasvatuksen pahin "vastustaja" ei ilmeisesti ole "väkivaltakasvatus" muodossa tai toisessa, vaan aikuisten persoonallisuuden köyhtyminen kulutuksen oravanpyörässä:

"'Tärkeimpien motivaatiosuuntien väliset sisäiset vuorovaikutussuhteet ihmisen toimintojen kokonaisuudessa muodostavat ikään kuin persoonallisuuden yleisen "psykologisen profiilin". Ajoittain se ilmenee litistyneenä, ilman todellisia huippuja. Ihminen pitää silloin elämän pieniä asioita suurina eikä näe suuria laisinkaan. Tällainen persoonallisuuden köyhyys voi tietyissä sosiaalisissa olosuhteissa liittyä hyvinkin laajaan jokapäiväisten tarpeiden tyydytykseen. Tällä tavoin muuten nykyajan kulutusyhteiskunta uhkaa psykologisesti ihmisen persoonallisuutta"' (Leontjev mt, 181).

"'Persoonallisuus ja sen kohtalo muodostuvat toisenlaisiksi, kun motiivitavoite on todella inhimillinen, ei eristä ihmistä, vaan yhdistää hänen elämänsä toisten ihmisten elämään ja heidän hyvinvointiinsa. Ihmisen osaksi tulleista olosuhteista riippuen tăllaiset elämăn motiivit voivat saada hyvinkin erilaisen sisällön ja erilaisen objektiivisen merkityksen, mutta ainoastaan tällaiset motiivit voivat luoda hănen olemassaololleen sisäisen psykologisen oikeutuksen, joka muodostaa elämän merkityksen ja onnen. Tämän tien huippukohta Gorkin sanojen mukaan on ihminen ihmiskunnan jäsenend" (Leontjev mt, 180).

Juuri tuo - ihminen ihmiskunnan jăsenenä - on rauhankasvatuksen tavoite. 


\section{Lähteet}

Antola E. (1977) Kehitysmaat maailmantaloudessa. Ulkopolitiikka 3/1877

Antola E. (1978) Epätasainen kasvu ja konfliktit Afrikassa. Ulkopolitiikka 3/1978

Arnkil E. (1982) Rauhankasvatus, maantieto ja oppimisprosessin ohjaaminen. Koulutyöntekijä 3/ 1982 ja 4/1982

Arnkil R. (1981) Motivoidaanko oppilaat käytănnollä? Koulutyöntekijä 3/1981

Baltes P. - Schaie K. (1973) (eds.) Life-span developmental psychology: personality and socialization. New York, London

Boshowitsch L.I. (1970) Die Persőhnlichkeit und ihre Entwicklung im Schulalter. Berlin

Dawydow V.V. (1977) Arten der Verallgemeinerung im Unterricht. Berlin

Dawydow V.V., Lompscher J. \& Markova A.K. (Hrsg.) (1982) Ausbildung der Lerntătigkeit bei Schülern. Berlin

Elkonin D.B. (1972) Zur Problem der Periodisierung der psychischen Entwicklung im Kindesalter. In Psychologische Probleme der Entwicklung sozialistischer Persőhnlichkeiten. Berlin

Engeström Y. (1979) Koululaisten mielikuvistus ja käyttäytyminen rauhankasvatuksen kannalta tarkasteltuna. Rauhan- ja konfliktintutkimuslaitos. Tutkimuksia no. 19.1979 Tampes

Engeström Y. \& Hakkarainen P. (1981) Is scientific Instruction Possible? NFPF tidskrift nr 2.1981

Engestrơm Y. (1982a) Orientointi opetuksessa. Valtion koulutuskeskus

Engeström Y. (1982b) Perustietoa opetuksesta. Helsinki

Galperin P.J. (1979) Johdatus psykologiaan. Helsinki

Haavelsrud M. (1981) (ed.) Approaching Disarmament Education. Guilford

Hakkarainen P. (1979) Mitä on kehittăvă opetus. Kasvatustieteiden tutkimuslaitos. Selosteita ja tiedotteita 128

Hveem H. (1979) Militarization of Nature: Conflict and Control over Strategic Resources and Some Implications for Peace. Journal of Peace Research No 1, vol XVI

Kekkonen H. (1982a) Aikuiskasvatus rauhan edistäjănă. Teoksessa Simola H. (1982) (toim.) Torstai toivoa tăynnä. Helsinki
Kekkonen H. (1982b) Ikkuna tulevaisuuteen. Uusikaupunki

Kouluhallitus (1981) Aseidenriisuntakasvatus peruskoulussa ja lukiossa: aseidenriisuntakasvatustyöryhmän muistio

Käkönen J. (1980) Kansainvälisen politiikan kehityspiirteitä. Väkivallan käytőstä kohti rauhanomaista rinnakkainoloa. Painopaikka mainitsematta

Leontjev A.N. (1977) Toiminta, tietoisuus, persoonallisuus. Kuopio

Levinson D. (1978) The seasons of a man's life. New York

Nasarowa N.S. (1976) Zu einigcn Problemen der Herausbildung einer kommunistischen Uberzeugung der Studenten. Teoksessa Engestrőm 1979

Onnismaa J. (1982) Kirjallisuudenopetus ja maailmankatsomus. Koulutyőntekijä 4/1982

Pehunen R. \& Lahtela K. (1982) Vanhenevan yksilön toimintakyky ja persoonallisuus: kuvausjärjestelmän kehittäminen. Kansanelăkelaitoksen kuntoutuskeskus. Turku

Petrovski A.V. (1974) (toim.) Yleinen psykologia kasvatusopillisia instituutteja varten. Helsinki

Seppä T. \& Vesa U. (1982) (toim.) Aseidenriisuntakasvatuksen kásikirja. Tampere

Talyzina N.F. (1981) The Psychology of Learning. Moscow

Teplov B. (1963) Psychological aspects of artistic education. Artikkelissa Onnismaa 1982

Unesco (1975) Kasvatus kansainvăliseen ymmärtämykseen, yhteistyöhön ja rauhaan. Helsinki: Opetusministeriö - Suomen YK-liitto

Unesco (1980) Aseidenriisuntakasvatuksen maailmankonferenssi, päătơsasiakirja teoksessa Seppä \& Vesa 1982

Viljo E-M. (1976) Esteettisen kasvatuksen perusteita. Artikkelissa Onnismaa 1982

Väyrynen R. (1980) Ristiriita ja yhteistyo lännen energiastrategiassa. Ulkopolitiikka 2/1980

Väyrynen R. (1983) Ydinaseet ja suurvaltapolitiikka. Helsinki

Wihtol R. (1978) Kansainvăliset alueelliset kehityspankit ja -rahastot. Ulkopolitiikka 3/1978

Young N. (1981) Educating the Peace Educators. Bulletin of Peace Proposals 2/1981 